\title{
Efficacy of cabbage root fly (Delia radicum L.) control based on monitoring system in cabbage crops
}

\section{Skuteczność zwalczania śmietki kapuścianej (Delia radicum L.) w uprawach kapusty głowiastej na podstawie monitoringu}

\author{
Maria Rogowska, Robert Wrzodak, Andrzej Lewandowski, Katarzyna Woszczyk
}

\section{Summary}

During the 2011-2012 the research on optimal treatment time to control cabbage root fly on cabbage crops was carried out. The study focused on determining the suitability of allylisothiocyanate-baited traps to control Delia radicum L. on cabbage crops. Treatment time was determined based on a number of captured females. During cabbage harvesting time an analysis of a root damaged caused by cabbage root fly larva was done. The results show a high efficacy of used monitoring system in control of $D$. radicum on cabbage crops. Flight monitoring method could be useful for control cabbage root fly in Integrated Pest Management.

Key words: Delia radicum; monitoring; control

\section{Streszczenie}

W latach 2011-2012, w Instytucie Ogrodnictwa oraz w gospodarstwie Zespołu Szkół Centrum Kształcenia Rolniczego w Powierciu prowadzono badania nad ustaleniem optymalnych terminów zwalczania śmietki kapuścianej (Delia radicum L.) na plantacjach warzyw kapustnych w sezonie wegetacyjnym. Badania dotyczyły określenia przydatności pułapki zapachowej oraz opracowania metod monitorowania nalotu i kontroli liczebności śmietki kapuścianej na warzywach kapustnych. Monitoring nalotu prowadzono przy użyciu pułapki zapachowej firmy Medchem. Terminy zabiegów zostały ustalone na podstawie liczby odłowionych samic. W okresie zbiorów wykonano analizę korzeni, licząc korzenie uszkodzone przez larwy śmietki kapuścianej. Uzyskane wyniki potwierdzają wysoką skuteczność zastosowanej metody monitoringu w zwalczaniu śmietki kapuścianej. Opracowywana metoda będzie podstawą do prowadzenia integrowanej ochrony warzyw kapustnych przed śmietką kapuścianą.

Słowa kluczowe: Delia radium; monitoring; zwalczanie 


\section{Wstęp / Introduction}

W Polsce, rośliny kapustne, pod względem łącznej powierzchni upraw, zajmują czołowe miejsce w ogólnej strukturze uprawianych warzyw (GUS 2013). Jednym z głównych szkodników warzyw kapustnych jest śmietka kapuściana (Delia radicum L.), która przy niewłaściwie prowadzonej ochronie plantacji często powoduje straty przekraczające 20\% plonu (Szwejda i Wrzodak 2006). W skrajnych przypadkach uszkodzenia plonu mogą sięgać 80\% (Szwejda 1975). W Polsce obserwuje się zazwyczaj 3 pokolenia tego szkodnika. Pierwsze, najczęściej uszkadza części podziemne wczesnych odmian warzyw kapustowatych. Drugie i trzecie pokolenie uszkadza także części nadziemne. Jedną z głównych przyczyn nieskutecznej ochrony przed szkodnikami są nieterminowo przeprowadzane zabiegi ochronne. Przy braku systemu monitoringu producenci najczęściej wykonują zabiegi w sierpniu, bez wiedzy czy szkodnik pojawił się już w polu (Szwejda i Wrzodak 2006). W związku z tym w Instytucie Ogrodnictwa w Skierniewicach podjęto badania nad ustaleniem optymalnych terminów zabiegów zwalczania śmietki kapuścianej na plantacjach warzyw kapustnych.

Celem badań było opracowanie metody sygnalizowania obecności śmietki z użyciem pułapek zapachowych, która pozwoli na precyzyjne ustalenie terminów jej nalotu na plantacje warzyw kapustnych oraz ustalenie optymalnych terminów przeprowadzenia zabiegów zwalczania. Dzięki temu, ograniczona zostanie liczba zabiegów i ilość stosowanych chemicznych środków ochrony roślin. Opracowywana metoda będzie podstawą do prowadzenia integrowanej ochrony warzyw kapustnych przed śmietką kapuścianą.

\section{Materiały i metody / Materials and methods}

Badania dotyczące ustalenia optymalnych terminów zwalczania śmietki kapuścianej na plantacjach warzyw kapustnych prowadzono na polach doświadczalnych Instytutu Ogrodnictwa w Skierniewicach, w latach 2011-2012, w uprawach wczesnej i późnej kapusty głowiastej. Powierzchnia każdej uprawy wynosiła $200 \mathrm{~m}^{2}$. W bada- niach określono przydatność pułapki zapachowej do monitorowania nalotu zapłodnionych samic i kontroli liczebności śmietki kapuścianej. Monitoring nalotu prowadzono przy użyciu pułapek zapachowych firmy Medchem, zawierających jako substancję wabiącą izotiocyjanian allilu (Traynier 1965; Eckenrode i Arn 1972; Finch i Skinner 1974, 1982). Pułapki umieszczano po dwie w każdej uprawie, na palikach pozwalających na zmianę wysokości ich mocowania tak, aby znajdowały się nad wierzchołkami rosnących roślin (Rogowska i Szwejda 2002; Szwejda i Wrzodak 2006). Odczyty liczby odłowionych samic śmietki prowadzono 2-3-krotnie w ciągu tygodnia, przez cały okres wegetacji. Jako metodę porównawczą, prowadzono lustrację upraw na obecność szkodnika i określano liczbę roślin ze złożonymi jajami śmietki. Na tej podstawie, po przekroczeniu progu ekonomicznej szkodliwości (znalezienie powyżej 10 jaj na 10 kolejnych roślinach) określono terminy przeprowadzenia zabiegów opryskiwania (Szwejda 2013). W tym celu użyto środka zawierającego substancję czynną - lambda-cyhalotryna w dawce 0,12 1/ha. W okresie zbiorów oceniono udział roślin zniszczonych oraz korzeni uszkodzonych przez larwy śmietki kapuścianej. Procent skuteczności określono według wzoru:

$$
\begin{gathered}
\text { procent skuteczności }= \\
100-\frac{1 . \text { uszkodz. roślin } \mathrm{w} \text { kombin. traktowanej } \times 100}{\text { 1. uszkodz. roślin } \mathrm{w} \text { kombin. kontrolnej }}
\end{gathered}
$$

\section{Wyniki i dyskusja / Results and discussion}

Liczba odławianych samic wszystkich trzech pokoleń była w roku 2011 mniejsza aniżeli w roku kolejnym (tab. 1, 2). W roku 2011 lot pierwszych samic I pokolenia odbył się w podobnym okresie, jak w roku 2012 i przypadał na II dekadę maja. Samice II pokolenia odłowione zostały w roku 2011 wcześniej niż w roku 2012, lecz w znacząco mniejszej liczbie. Lot pierwszych samic III pokolenia w roku 2011 miał miejsce 2 dni wcześniej niż $\mathrm{w}$ roku następnym.

Tabela 1. Wyniki monitorowania nalotu śmietki kapuścianej i terminy wykonania zabiegów zwalczania w roku 2011 Table 1. Number of captured D. radicum females and terms of treatments in 2011

\begin{tabular}{l|c|c}
\hline & $\begin{array}{c}\text { I pokolenie } \\
\text { First generation }\end{array}$ & $\begin{array}{c}\text { II pokolenie } \\
\text { Second generation }\end{array}$ \\
\hline $\begin{array}{l}\text { Lot pierwszych samic } \\
\text { Flight of first females }\end{array}$ & $15-18.05$ & $1-4.07$ \\
\hline $\begin{array}{l}\text { Liczba odłowionych samic } \\
\text { Number of captured females }\end{array}$ & 34 & 11 \\
\hline $\begin{array}{l}\text { Terminy zabiegów według sygnalizacji } \\
\text { przy pomocy pułapek zapachowych }\end{array}$ & $17.05,24.05$ & $4.07,11.07$ \\
$\begin{array}{l}\text { Dates of treatments established on traps signalization } \\
\begin{array}{l}\text { Terminy zabiegów na podstawie lustracji roślin } \\
\text { (próg ekonomiczny) }\end{array}\end{array}$ & & 8 \\
$\begin{array}{l}\text { Dates of treatments established on plant inspections } \\
\text { (economic threshold) }\end{array}$ & $23.05,30.05$ & - \\
\hline
\end{tabular}


Tabela 2. Porównanie metod ustalania terminu zabiegu i ich wpływ na liczbę uszkodzonych roślin przez larwy I i II pokolenia śmietki kapuścianej (D. radicum) w roku 2011

Table 2. Comparison of treatment signalization methods and its influence on number of damaged plants caused by I and II generation of cabbage root fly larvae in 2011

\begin{tabular}{l|c|c|c}
\hline \multicolumn{1}{c|}{\begin{tabular}{c}
\multicolumn{1}{c|}{$\begin{array}{c}\text { Kombinacja } \\
\text { Combination }\end{array}$} \\
\cline { 2 - 4 }
\end{tabular}} & $\begin{array}{c}\text { Dawka } \\
\text { Dose } \\
{[1 / \mathrm{ha}}\end{array}$ & $\begin{array}{c}\text { Średnia liczba uszkodzonych roślin/poletko (40 roślin) } \\
\text { Average number of damaged plants } \\
\text { on plot (40 plants) }\end{array}$ \\
\hline $\begin{array}{l}\text { Lambda-cyhalothrin } \\
\text { (sygnalizacja - pułapki) } \\
\text { (sygnalization - traps) }\end{array}$ & 0,12 & $\begin{array}{c}\text { I pokolenie } \\
\text { first generation }\end{array}$ & 0,25 \\
\hline $\begin{array}{l}\text { Lambda-cyhalothrin } \\
\text { (sygnalizacja - lustracja roślin) } \\
\text { (sygnalization - plant inspection) }\end{array}$ & 0,12 & 1,5 & 0,5 \\
\hline Kontrola - Control & - & 2,50 & 0,5 \\
\hline
\end{tabular}

Tabela 3. Wyniki monitorowania nalotu śmietki kapuścianej i terminy wykonania zabiegów zwalczania w roku 2012

Table 3. Number of captured D. radicum females and terms of treatments in 2012

\begin{tabular}{l|c|c|c}
\hline & $\begin{array}{c}\text { I pokolenie } \\
\text { First generation }\end{array}$ & $\begin{array}{c}\text { II pokolenie } \\
\text { Second generation }\end{array}$ & $\begin{array}{c}\text { III pokolenie } \\
\text { Third generation }\end{array}$ \\
\hline $\begin{array}{l}\text { Lot pierwszych samic } \\
\text { Flight of first females flight }\end{array}$ & $15-20.05$ & $23-26.07$ & $31.08-3.09$ \\
\hline $\begin{array}{l}\text { Liczba odłowionych samic } \\
\text { Number of captured females }\end{array}$ & 46 & 142 & 37 \\
\hline $\begin{array}{l}\text { Terminy zabiegów według sygnalizacji } \\
\text { przy pomocy pułapek zapachowych }\end{array}$ & $21.05,28.05$ & $23.07,30.07$ & - \\
$\begin{array}{l}\text { Dates of treatments established on traps signalization } \\
\begin{array}{l}\text { Terminy zabiegów na podstawie lustracji roślin } \\
\text { (próg ekonomiczny) }\end{array}\end{array}$ & $26.05,2.06$ & $27.07,3.08$ & - \\
$\begin{array}{l}\text { Dates of treatments established on plant inspections } \\
\text { (economic threshold) }\end{array}$ & & & \\
\hline
\end{tabular}

Tabela 4. Porównanie metod ustalania terminu zabiegu i ich wpływ na liczbę uszkodzonych roślin przez larwy I i II pokolenia śmietki kapuścianej (D. radicum) w roku 2012

Table 4. Comparison of treatment signalization methods and its influence on number of damaged plants caused by I and II generation of cabbage root fly larvae in 2012

\begin{tabular}{|c|c|c|c|}
\hline \multirow{2}{*}{$\begin{array}{l}\text { Kombinacja } \\
\text { Combination }\end{array}$} & \multirow{2}{*}{$\begin{array}{l}\text { Dawka } \\
\text { Dose } \\
{[1 / \text { ha }]}\end{array}$} & \multicolumn{2}{|c|}{$\begin{array}{c}\text { Średnia liczba uszkodzonych roślin/poletko (40 roślin) } \\
\text { Average number of damaged plants } \\
\text { on plot ( } 40 \text { plants })\end{array}$} \\
\hline & & $\begin{array}{c}\text { I pokolenie } \\
\text { First generation }\end{array}$ & $\begin{array}{c}\text { II pokolenie } \\
\text { Second generation }\end{array}$ \\
\hline $\begin{array}{l}\text { Lambda-cyhalothrin } \\
\text { (sygnalizacja - pułapki) } \\
\text { (sygnalization - traps) }\end{array}$ & 0,12 & 1,5 & 4,0 \\
\hline $\begin{array}{l}\text { Lambda-cyhalothrin } \\
\text { (sygnalizacja - lustracja roślin) } \\
\text { (sygnalization - plants inspection) }\end{array}$ & 0,12 & 4,25 & 8,25 \\
\hline Kontrola - Control & - & 19,5 & 28,0 \\
\hline
\end{tabular}

Termin zabiegu na podstawie lustracji roślin przypadał średnio 4,5 dnia później w porównaniu do terminu zabiegu na podstawie sygnalizacji prowadzonej według odłowów za pomocą pułapek zapachowych. Największa różnica w terminie zabiegów miała miejsce w roku 2011, w przypadku pokolenia I. Wynosiła ona 6 dni i ze względu na biologię szkodnika może być ona dla praktyki ochrony roślin znacząca (Szwejda 1975).

Średnia skuteczność wszystkich zabiegów w porównaniu $\mathrm{z}$ kombinacją kontrolną z obu lat prowadzenia badań wyniosła $84 \%$. Średnia skuteczność przeprowadzonych zabiegów w roku 2011 wynosiła $86,8 \%$, natomiast w roku 
2012 było to $81,7 \%$. Skuteczność zwalczania I pokolenia w obu latach badań wynosiła średnio $84,5 \%$, a II pokolenia $84,1 \%$. We wszystkich przypadkach skuteczność zabiegu wyznaczona za pomocą sygnalizacji była wyższa niż wyznaczona za pomocą lustracji roślin i wynosiła od 85,7 (zwalczanie drugiego pokolenia w roku 2012) do 93,3\% (zwalczanie drugiego pokolenia $\mathrm{w}$ roku 2011) w porównaniu do kombinacji kontrolnej (tab. 3, 4). Skuteczność zabiegów wykonanych na podstawie lustracji roślin wynosiła od 70,5 (zwalczanie drugiego pokolenia w roku 2012) do $86,7 \%$ (zwalczanie drugiego pokolenia w roku 2011) w porównaniu do kombinacji kontrolnej.

Inni autorzy, stosując odmienne metody wyznaczania terminu zabiegu przeciwko śmietce kapuścianej uzyskiwali niższą skuteczność zastosowanych środków ochrony. Przykładowo Bažok i wsp. (2012) wykonując zabieg opryskiwania w momencie stwierdzenia pojawienia się jaj osiagnnęli skuteczność do $67 \%$, oceniając ją na podstawie udziału uszkodzonych roślin. Rogowska i Szwejda (1998) w swoich badaniach przeprowadzili zabieg opryskiwania chrzanu w okresie wschodów. Ich skuteczność zawierała się w przedziale 43,5-80\% liczby uszkodzonych korzeni.

\section{Wnioski / Conclusions}

1. Wyniki uzyskane z przeprowadzonych odłowów przy użyciu pułapek zapachowych pozwoliły na określenie terminu nalotu śmietki kapuścianej. W przeprowadzonych badaniach stwierdzono, że początek okresu nalotu samic na uprawę miał miejsce w połowie maja dla pokolenia pierwszego, w lipcu dla pokolenia drugiego i pod koniec sierpnia dla pokolenia trzeciego.

2. Najlepsze efekty chemicznego zwalczania śmietki kapuścianej uzyskano, gdy termin zabiegu ustalony został na podstawie odłowów dokonanych za pomoca pułapek zapachowych.

3. Zastosowane pułapki zapachowe wykazały pełną przydatność w odławianiu samic śmietki kapuścianej i powinny być używane w integrowanej ochronie w ramach systemów ostrzegających o zagrożeniu upraw.

Praca została wykonana w ramach zadania 1.14 ,Prognozowanie zagrożeń powodowanych przez fitofagi występujące na uprawach roślin warzywnych" wchodzącego W skład Programu Wieloletniego „Rozwój zrównoważonych metod produkcji ogrodniczej w celu zapewnienia wysokiej jakości biologicznej i odżywczej produktów ogrodniczych oraz zachowania bioróżnorodności i środowiska i ochrony jego zasobów", finansowanego przez Ministerstwo Rolnictwa i Rozwoju Wsi.

\section{Literatura / References}

Bažok R., Ceranić-Sertić M., Igrc Barčić J., Borošić J., Kozina A., Kos T., Lemić D., Čačija M. 2012. Seasonal flight, optimal timing and efficacy of selected insecticides for cabbage maggot (Delia radicum L., Diptera: Anthomyiidae). Control. Insects (3): $1001-1027$.

Eckenrode C.J., Arn H. 1972. Trapping cabbage maggots with plant bait and allyl isothiocyanate. J. Econ. Entomol. 65 (5): $1343-1345$.

Finch S., Skinner G. 1974. Some factors affecting the efficiency of water traps for capturing cabbage root flies. Ann. Appl. Biol. 77: 213-226.

Finch S., Skinner G. 1982. Trapping cabbage root flies in traps baited with plant extracts andwith natural and synthetic isothiocyanates. Entomol. Exp. Appl. 31: 133-139.

GUS 2013. Rocznik Statystyczny Rolnictwa 2012. Zakład Wydawnictw Statystycznych, Warszawa.

Rogowska M., Szwejda J. 1998. Dynamika występowania niektórych szkodników chrzanu, z uwzględnieniem zwalczania śmietki kapuścianej (Delia radicum L.). [Occurrence dynamics of some pests and control of cabbage root fly (Delia radicum L.) on horseradish]. Prog. Plant Prot./Post. Ochr. Roślin 38 (1): 180-185.

Rogowska M., Szwejda J. 2002. Porównanie dwóch typów pułapek do odławiania imagines śmietki kapuścianej (Delia radicum L.). [Comparison of two trap types to catch of cabbage root fly adults (Delia radicum L.)]. Prog. Plant Prot./Post. Ochr. Roślin 42 (2): $622-624$.

Szwejda J. 2013. Progi zagrożenia dla ważniejszych gatunków szkodników występujących na uprawach roślin warzywnych. s. 144-148. W: Program Ochrony Rośliny Warzywne. Hortpress, Warszawa, 302 ss.

Szwejda J. 1975. Ekologia śmietki kapuścianej Hylemya brassicae (Diptera: Anthomyiidae). Rocz. Nauk Rol. 5: 43-74.

Szwejda J., Wrzodak R. 2006. Ogólnopolski system monitorowania śmietki kapuścianej na plantacjach warzyw kapustowatych. [Nationwide system for monitoring of cabbage root fly (Delia radicum) on cabbage plantations in Poland]. Prog. Plant Prot./Post. Ochr. Roślin 46 (1): 270-275.

Traynier R.M.M. 1965. Chemostimulation of oviposition by the cabbage root fly, Erioischia brassicae (Bouche). Nature (London) 207: $218-219$ 